\title{
Sociabilidades políticas e relações de gênero: ritos domésticos e religiosos no Rio de Janeiro do século XIX
} Political sociabilities and gender relationships:
domestic-religious rites in 19th century Rio de Janeiro

Suely Gomes Costa*

\section{RESUMO}

Este artigo, com base em fontes diversas, especialmente textos literários e relatos de viagens, analisa ritos doméstico-religiosos tais como o batismo de escravos em igrejas de negros e a educação religiosa dos mestres de reza, dentre outros, no Rio de Janeiro do século XIX, como expressão de sociabilidades políticas. Propõe-se a analisar padrões de domesticidade e intimidade em processos de longa duração histórica, admitindo-os como indissociáveis das relações de gênero, bem como suas interseções com outras relações sociais (classe/raça/etnia/geração).

Palavras-chave: sociabilidades políticas; ritos doméstico-religiosos; relações de gênero e outras relações sociais (classe/raça/etnia/geração).

\section{ABSTRACT}

This article is based on several sources, especially literary texts and traveler's accounts for the analysis of religious and domestic rites such as the baptism of slaves in exclusively 'black' churches and in the religious education of the prayer leaders, besides others, in Rio de Janeiro at the dawn of the $19^{\text {th }}$ century, as an expression of social politics. It proposes the analysis of standards of domesticity and intimacy patterns in social processes of historically long duration, considering them inseparable from gender relations within the context of social relations, and their relationship with other categories of social relations (class/ gender/race/ ethnicity/generation).

Keywords: political sociabilities; domestic-religious rites; gender relations and other social relations (class/gender/race /ethnicity/generation).

\footnotetext{
* Pesquisadora do CNPq. Programa de Estudos Pós-Graduados em Política Social. Rua Visconde de Rio Branco s/n, Bloco E, 3º andar - Campus Universitário do Gragoatá. 24210-190 Niterói - RJ - Brasil. suelygom@oi.com.br.
} 
Relações escravistas, por muito tempo examinadas a partir de rígidas oposições entre senhores e escravos e de um inexorável sistema de poder que tudo submete, firmaram conceitos sobre sociabilidades antagônicas, esmaecendo campos de convergência e de consenso que esses mesmos sujeitos constroem em suas práticas cotidianas. ${ }^{1}$ Das revisões historiográficas processadas, contribuições que incidem sobre experiências humanas singulares e que se voltam para relações sociais presentes na escravidão doméstica e nas de homens e mulheres livres em suas moradas, muito têm evidenciado de "jogo de interesses ... correspondências entre os pertencimentos sociais e ... escolhas políticas". ${ }^{2}$ As moradas, percebidas também como lugares de intrincadas associações femininas, expõem sociabilidades políticas, forjadas em oposições e concordâncias, não só entre escravos e senhores, mas entre homens e mulheres, escravos e livres, sob muitas circunstâncias. Este artigo examina alguns ritos doméstico-religiosos no Rio de Janeiro, ao longo do século XIX, como uma forma de expressão dessas sociabilidades, mas de sujeitos históricos que se movem nas complexas relações sociais de gênero e suas interseções com as de classes sociais, de raças/etnias, de gerações, presentes na organização e administração das práticas cotidianas. Os sinais políticos desses ritos são plurais e, em muitos momentos, convergem para um campo de interesse comum ou para um "horizonte de expectativas" partilhado por diferentes sujeitos, considerando possibilidades de ganhos para todos, ainda que de diferentes pesos e sentidos; essa circunstância parece definir pactos e contratos e também muitas identidades. ${ }^{3}$ Esses ritos situam também obrigações recíprocas entre pessoas neles envolvidas e elos de cadeias associativas que se propagam através de redes sociais que ensejam. ${ }^{4}$ Associam práticas sociais das moradas com as das religiões, ambas partes da mesma experiência cultural. Mostram o caráter indissociável das relações entre as esferas pública e privada.

Dentre os ritos examinados, os batismos fixam responsabilidades públicas exercidas na esfera privada; nessas circunstâncias, um conjunto de deveres e obrigações é 'natural' e informalmente cumprido. Embora de muitos feitios, mostram que a cada vida iniciada correspondem compromissos presentes e futuros selados nas relações de compadrio. Regras de convivência entre padrinhos, madrinhas, afilhadas e afilhados projetam um horizonte de expectativas quanto a cuidados recíprocos presentes e futuros regulados em costumes. Ritos como os dos batismos, tornam nítidas algumas redes sociais, bastando lembrar que proles numerosas desses tempos colocam em cena muitas crianças, padrinhos e madrinhas. Outros mais jogam luz sobre processos civilizadores de muitos sentidos, através de representações forjadas em rela- 
ções sociais de gênero em suas interseções com as de classes, raças/etnias e gerações, reiteradas e engendradas nas moradas. Aqueles aqui examinados ocorrem no Rio de Janeiro do século XIX.

A celebração do batismo de escravos adultos, recém-chegados da África, sós, ou no caso de mulheres, com seus filhos, por exemplo, se organiza através de uma combinação de regras domésticas com outras religiosas, institucionais, e firma compromissos nada irrisórios. É o caso do cerimonial de batismos desses escravos em igrejas servidas por padres negros, como a "Velha Sé no fim da rua do Rosário; a Lampadosa, perto do Tesouro e a de São Joaquim..., observadas por Debret, em sua passagem pelo Rio (1816-1830). ${ }^{5}$ Distingue ele um padrão de compadrio de muitos deveres, irrisórios só na aparência, num momento inaugural de vida de escravos e escravas na terra estranha. O rito, sempre conduzido por um padre negro, brasileiro, nesse espaço apartado dos brancos, parece destinado a fazer que esses recém-chegados reconheçam, nessa presença, laços identitários, e a vejam com autoridade capaz de lhes facilitar o trânsito para esse novo modo de vida.

Na cena ilustrada por Debret, dois negros, um homem e uma mulher, certamente escolhidos por seus proprietários, posam respectivamente de madrinha e padrinho para duas escravas e seus filhos, recém-chegados da África. Oferecem, assim, aos recém-chegados, exemplos de condutas a serem seguidos, mas também, possivelmente, imagens de mãe e pai reconstituídas nessa nova terra. De fato, o padrinho, em casos análogos, informa Debret, era sempre o "escravo mais antigo" ou, como de uso nas casas mais ricas, "o mais virtuoso". Esse observador examina o rito "do ponto de vista político", deduzindo tratar-se de "uma garantia para os senhores obrigados a dirigir uma centena de escravos reunidos", muito mais que um ato de profissão de fé religiosa. Nessa nota, Debret traduz esse rito como um jogo de interesses, expresso num contrato de fins subentendidos, de interesse dos senhores no controle da rebeldia dos escravos, e dos escravos no compromisso de proteção social de seus senhores.

De fato, nessa experiência, padres negros, em suas igrejas de negros, parecem se colocar a serviço da obrigatoriedade do batismo de escravos que, na legislação portuguesa, pode servir de interdição à nulidade de casamentos entre escravos e à venda de membros de uma família escrava em separado. Nesses termos, protege a formação da família escrava. Ainda que possam parecer frouxos e tantas vezes descumpridos, ritos como esse sugerem práticas direcionadas para um campo de convergência de interesses recíprocos de senhores e escravos. As observações de Debret sobre o ritmo apressado desse rito, 
entretanto, denunciam o caráter irrisório desse batismo como prática religiosa, mas também indicam a urgência e a tolerância da Igreja na conduta em que basta "uma simples instrução preliminar acerca da crença religiosa para satisfazer a exigência do padre”.

A ilustração de Debret marca fortemente o contraste entre a austera e comedida imagem da madrinha coberta da cabeça aos pés e a extravagante figura das catecúmenas, tão despidas. ${ }^{6}$ Num tempo de trajes femininos longos, as escravas portam camisolas brancas curtas, pouco abaixo dos joelhos, cheias de babados rendados; cintos largos e acetinados de cor rosa e azul, fechados em grandes laços às costas; colo, ombros e costas inteiramente nus, com enormes brincos e colares dourados de muitas voltas. Essas vestes femininas reproduzem o modelo dos vestidinhos enfeitados de batizado das crianças que as escravas trazem ao colo, como que a reafirmar para mães e filhos seus mesmos significados. Trata-se de um 'uniforme' de batismo para adultos e crianças, modo de produzir um signo de identidade ritual e só por isso, tolerado pela Igreja? Por que é aceito pelas igrejas de negros o uso de vestes femininas tão bizarras? Mesmo que fossem sobras aproveitadas, à última hora, de saias ou anáguas das sinhás, elas oferecem um contraponto à atitude de 'reserva discreta' da madrinha, o exemplo feminino a ser seguido pelas escravas.

Com igual estranhamento fala Debret das vestes da cerimônia de batismo de negros adultos também recém-chegados. Alguns deles, "mais inteligentes ou simplesmente mais idosos e envergonhados com a sua fantasia, em que a calça contrasta de maneira ridícula com a elegante túnica que lhes cobre os rins, procuram, durante o trajeto, colar-se aos muros das casas, a grande distância de seus padrinhos". Debret sente o constrangimento dos africanos vestidos nesse ritual de estranhos costumes. As vestes do piedoso padrinho e dos escravos, do mesmo modo que as da madrinha e dessas mulheres negras chegadas ao Brasil, nada sugerem em comum, senão constrangimentos. Que motivações existem no uso de vestes tão estranhas? Práticas religiosas como essa, são, de fato, como pensa Debret, experiências capazes de traduzir escolhas políticas de proprietários de escravos, na tentativa de 'domesticar' possíveis rebeldias? Ou são uma possibilidade de restaurar, no plano simbólico, signos de pertença, remetendo africanos recém-chegados a antigos legados culturais através das representações masculinas de padres, padrinho negros e das igrejas de negros? De todo modo, fixa um horizonte de expectativas dos senhores quanto à convivência possível, com garantia de controle da rebeldia escrava e dos escravos e de proteção social nessa terra, ainda tão desconhecida, fazendo germinar novas pertenças. 
Uma outra cerimônia, a dos mestres de reza, alarga essas experiências iniciais de escravos recém-chegados no tocante à prática religiosa. Trata-se de um costume usual das moradas do Rio de Janeiro, pelo menos até a década de 1840. Na primeira década do século XIX, Marrocos, português e funcionário do Paço, recém-chegado ao Rio de Janeiro, sem família, logo comunica em carta ao pai sua decisão de tomar para si um negro, recém-chegado de Cabinda. ${ }^{7}$ Assinala aí a prática de contratar velhos negros livres, nesses tempos, como "professores dos princípios da religião católica ... principalmente apreciados porque têm a vantagem de falar várias línguas africanas...", indicando as origens étnico-raciais desses mestres. Mostra a intenção de contratar para seu jovem escravo as aulas de um velho mestre-de-reza: "Quando eu o puder dispensar, hei de mandar ensiná-lo a rezar a doutrina que disso pouco sabe; eu não tenho pachorra; e aqui há clérigos inabilitados que vivem de ensinar doutrina aos escravos".

Há, nessa conduta, um modo de empregar parte do tempo do escravo em sua própria cristianização, enlaçando-o nessa cultura. As práticas dos mestres de reza aproximam os recém-chegados de formas de convivência com iguais em seus destinos sob o poder disciplinar desses mestres. Talvez para os escravos essa figura masculina encarne, como os padres negros de igrejas de negros, frações de códigos religiosos e de proteção já vividos nas suas áreas de origem e lhes ofereça a retomada de convivência grupal, recompondo continuidades culturais interrompidas, capazes de criar novas referências para expectativas e projetos de vida.

Manuel Antonio de Almeida, na sua narrativa literária sobre o sargento de milícias, informa que o mestre-de-reza circulava com grande desembaraço pelas casas do Rio de Janeiro. Em tom memorial, situa essa mesma prática no tempo e emite sobre ela uma nota esclarecedora: "Havia no tempo em que se passavam essas cenas instituições muito curiosas no Rio de Janeiro; algumas eram notáveis por seus fins, outras por seus meios. Entre essas uma havia de que ainda em nossa infância tivemos ocasião de ver alguns destroços". 8 A decadência dessa prática à época da publicação do seu livro - década de 1840 - talvez corresse por conta de sociabilidades nascidas na recuperação das religiosidades africanas em conhecidos hibridismos com as católicas, ou no desenvolvimento de novas religiosidades católicas por iniciativa das igrejas e ordens religiosas de pretos. No passado, desfrutara o mestre-de-reza de muito prestígio. Além disso, "dava-se uma circunstância muito notável ... eram sempre velhos e cegos". Como eram muito poucos, "viviam, portanto, em 
grande atividade, e ganhavam sofrivelmente. Andavam pelas casas a ensinar a rezar aos filhos, crias e escravos de ambos os sexos".

Esse autor, através da vida doméstica de sua personagem, D. Maria, detalha a presença do seu mestre-de-reza entre as crias, como usual. Descreveuo com um cego, uma pessoa venerada e reconhecida por seus dotes, que detinha ainda "a fama de bom arranjador de casamento". Esse é um outro rito que parece confirmar, mais uma vez, o intento de favorecer o processo de formação de famílias escravas. No caso narrado, Almeida detalha essa prática de catequese como se a estivesse vendo: a lição se desenvolve numa reunião, de homens e mulheres juntos, sentados em semicírculo. Ao iniciá-la, o mestre-de-reza "puxava do bolso a tremenda férula, colocava-a no chão, encostada à cadeira onde se achava sentado e começava o trabalho". Esse instrumento, ainda que associado a alguma forma de castigo, não define o clima em que ocorrem os modos de convivência nesses encontros. A tarefa inicial, o ensino do sinal da cruz, faz-se acompanhar do coro formado por todos os discípulos. Quando cegos, como esse, os mestres-de-reza, incapacitados para o exercício do controle dos gestos, usam, esclarece Almeida, a audição. Através da voz, podem corrigir os faltosos, interrompendo a reza sempre que "alguém se atrevia a deixar-se ficar calado. Suspendia-se então o trabalho e o culpado era obsequiado com uma remessa de bolos". A aula é concluída com a ladainha cantada. Na saída, o mestre-de-reza recebe da dona da casa uma pequena espórtula.

É provável que práticas religiosas como essas sejam as mesmas avaliadas por Burlamaque, em 1837, ao mostrar-se preocupado com as formas de propagação da catequese católica entre os escravos: 9 "Com efeito, todo o culto que entre nós se ensina aos escravos consiste em um batismo irrisório e em algumas rezas ... que certamente os encheria de indignação se os entendessem". Essa prática religiosa, a seu ver, infringe preceitos cristãos diante de "regras ... aprendidas à força de castigo.... E conclui: “Que idéia farão eles de uma religião de caridade e misericórdia que se lhes incute por meio de maus tratos?”. Entretanto, os mestres-de-reza não apenas introduzem seus discípulos nesses códigos religiosos, mas lhes revelam novas possibilidades de pertença. Isso autoriza pensar na teatralização em torno desses 'bolos', considerando que esse ritual aproxima homens e mulheres e os conduz a possíveis casamentos. $\mathrm{O}$ mestre-de-reza, mesmo em meio a tantas dificuldades de comunicação, parece fixar, também num rito curto e sumário, algumas regras reconhecíveis de disciplina com punição, mas não só: havia nelas a germinação de relacionamentos novos, de novas sociabilidades. 
Outras formas de batismo ocorrem ao mesmo tempo e em tempos diversos desses, lembrando que os fluxos de escravos se iniciam em meados do século XVI e prosseguem. Afinidades, identidades e consangüinidades estão presentes em tradições de convivência de sucessivas gerações de senhores e escravos nas mesmas moradas. Amas e pajens, independentemente do selo do batismo religioso, compõem há muito tempo redes de compadrio e de proteção social. Filhos e filhas de amas servem, sucessivamente, às gerações seguintes de senhores. Com isso, vinculam, de forma indissociável, seus ciclos de vida aos das famílias proprietárias. É usual a prestação de serviço de filhos e filhas de amas às sucessivas gerações de proprietários, associando-os todos, reciprocamente, às mesmas prescrições, ainda que, em muitos casos, debaixo de muitas tensões e conflitos. Na fazenda fluminense em que residira na década de 1880, Ina von Binzer, uma educadora alemã de crianças brasileiras, filhas de fazendeiros, descreve um batismo, a seu ver, muito estranho. ${ }^{10} \mathrm{Nessa}$ experiência doméstica, uma cerimônia grupal expõe o entrelaçamento de diferentes gerações de escravos e senhores. Na casa principal, na sala de costuras, um "importante armário" transformara-se em altar. Mais uma vez, a presença de um escravo piedoso está associada a um velho escravo, o alfaiate, que, paramentado, coadjuva o padre nesse batismo: "Então, uma após a outra, vieram as mães pretas com seus rebentos mais novos, todos muito bem vestidos e enfeitados com fitas de diversas cores; alguns tinham até vestidinhos brancos bordados". Ina atribui a feitura dessas vestes às filhas do fazendeiro "que se haviam prestado a servir de madrinhas, fazendo cristãos a seus irmãozinhos pretos...”. Nesse ritual, comum a muitas casas do Rio e de outras províncias do país, firmam-se recíprocas obrigações para o futuro. Esse tipo de domesticidade projeta sociabilidades à frente desse tempo para crianças brancas e negras, pretendendo o estreitamento de seus elos de compadrio. São códigos peculiares à formação dessas redes de proteção e dependências, base de concessões de alforrias e de destinações de bens a escravos e escravas em tantos inventários.

Desse mesmo código fazem parte os carinhosos gestos dessas pequenas alunas de Ina von Binzen, em relação às suas amas ou ao seu irmão de leite. Em seus registros sobre essa intimidade, Ina, apesar de sua perspicácia, não se deu conta de que o modo comovente e o ar de superioridade adotados pelos adultos brancos, e mesmo pelas crianças, no trato dos pretos - a seu ver, regra geral, de aspecto tão "humorístico" - fazem parte de um mesmo código relacional forjado em muitos séculos. Observará que as crianças "se afeiçoam aos bons e aos fiéis pretos e pretas...", deixando de assinalar que isso não as 
impede de delimitar todas as fronteiras dessa intimidade doméstica. Ela não distingue essas fronteiras quando destaca o carinhoso gesto de uma das filhas do fazendeiro, de apenas cinco anos idade, Maria da Glória, que "guarda um pouco de sobremesa para a ama, uma jovem e linda mulata, pedindo sempre qualquer coisa para seu irmão de leite também...”; ou aquele de Alfonsina, irmã dela, que por gostar de enfeites, "oferece sua fita multicor a sua velha aia" (Binzer, 1982, p.22). Nessas relações, ocorrem também rupturas. Ações corriqueiras, como essas, nunca apagam as marcas das distâncias entre senhores e escravos das várias gerações, traçadas, tantas vezes, com grande violência explícita ou simbólica.

Ina não entenderá o sentido da informação de sua aluna sobre um critério de escolha do nome do irmão - provavelmente um velho costume - que demarca o lugar de cada um. Seu irmão Plinius, "segundo me contou Lavínia, devia chamar-se Tiberius, não recebendo este nome, por ser comum entre os pretos" (p.81). Nesse tipo de convivência, códigos como esses, contraditoriamente, negam identidades e protegem os senhores da alegada intimidade familiar com seus servidores domésticos, tão reclamada pelos europeus. $\mathrm{Na}$ falta de um sobrenome, num comportamento às avessas ao dos senhores quanto ao nome de seus herdeiros, é usual que os escravos adotem, “em geral, depois de livres, o da família dos antigos senhores". Ina von Binzer, distante desses códigos culturais, vê nessa conduta uma homenagem aos senhores: “Agradável para estes, não é?” (p.35). Escapa-lhe o sentido dessa adoção. Garantem esses nomes um reconhecimento das origens, um escudo de proteção para muitos expedientes, até mesmo para afirmar identidades e pertenças. Nessa adoção, os escravos as assinalam, num meio que lhes é hostil; esses sobrenomes filiam-nos de um modo irrefutável; dão-lhes identificação negando a prática habitual de nomeá-los, através de marcas do corpo ou de procedência, como, de hábito, segundo escolhas de seus proprietários por tanto tempo chamando-os "de Cabinda", "de Angola" ou "de Moçambique".

Amas e pajens, na intimidade das casas, reafirmam compromissos desde longe conhecidos. Basta que algumas crianças de um mesmo grupo familiar sejam batizadas para que todas se vejam incluídas no laço pessoal e no círculo social estabelecido nesse rito. Uma pertença coletiva é selada nesse modo de compadrio extenso de muitas filiações desde cedo. Cada criança branca ganhava uma criança negra, seu pajem, e cada pajem uma criança branca, ambas vigiadas de perto por uma mucama, pela mãe, por parentes e compadres e comadres de todos os lados. As crianças negras, ainda que cercadas de tantas contenções, aprendem a colocar limites às experiências de poder das crian- 
ças brancas; e vice-versa. Cada uma delas experimenta o exercício do poder, ora na condição de carcereira, ora na de prisioneira uma da outra. Recebendo e cumprindo responsabilidades, as famílias de sangue e afins dividem e partilham entre si inúmeras tarefas da esfera da reprodução, cuidando de cada criança, uma a uma. Senhores, senhoras, pajens e mucamas compõem o corpo de mútua vigilância posto a cumprir as regras de convivência nesse ambiente.

De modo bastante regular, os escravos domésticos asseguram-se de acentuado destaque na hierarquia escrava; isso os diferencia ainda mais quando retiram daí alguns ganhos. O poder das amas se reafirmará em mais ritos de batismos doméstico-religiosos. Há também hierarquias diversas nesses compadrios: madrinhas e padrinhos de crisma e madrinhas de carregação e de consagração são as mais notáveis. Era usual que madrinhas de carregação conduzissem crianças, ainda pagãs, sempre no percurso entre a casa e a igreja, ou no trajeto interno das casas até os oratórios. Num desenho, Debret atribui essa carregação de crianças da rua para a entrada da igreja, de modo restrito, às "parteiras" (Debret, 1954, Prancha 12). Descreve essa prática como própria às classes médias: a pé ou em liteira de aluguel, a criança conduzida pela escrava era entregue ao padrinho (p.168). Mas não apenas essas classes a prestigiam. No batizado da princesa Isabel, em 15 de novembro de 1846, conta Ida Pfeiffer, a ama-de-leite participara do cortejo público, ao lado do Imperador, circulando com ela em torno do Paço Imperial - também do lado de fora da igreja -, cercada de altos dignitários da corte. O transporte da criança na igreja, porém, será feito por um veador; a Imperatriz e suas damas a aguardavam no interior da Igreja. ${ }^{11}$

Mesmo em tempos recentes, persistem ritos com madrinhas de carregação e de consagração. Estas últimas conduzem as crianças ao altar e as transferem aos padrinhos de batismo. As outras seguram a criança depois de batizada, numa curta cerimônia de consagração a um santo escolhido como seu protetor, geralmente, diante de um altar secundário, numa outra forma de gravar hierarquias, proximidades e papéis substitutos na linhagem dos compadrios, enlaçada nesses ritos.

Expilly, que tanto menosprezara os costumes brasileiros, irá referir-se a uma outra forma ritual de batismo doméstico ao falar da dedicação da ama de leite a sua filha recém-nascida, a mesma recebida por sua esposa, brasileira como ela. Sua carta à filha registra o discurso de despedida dessa ama, um precioso testemunho do batismo de leite: "Ela pedia-te entre lágrimas, como se pudesses compreender, que nunca esquecesses daquela que todos os dias te 
embalava nos braços e te fazia adormecer no seio. E se algum dia fosses rica, que a comprasses para ser só tua...." ${ }^{12}$ As amas tecem essa intimidade tradicional no trato cotidiano das crianças, revigorando enlaces de pessoas desiguais socialmente. São muitas as representações de fidelidade e de carinho referidas à extensão do colo materno, mas sem dispensar em muitos casos a vigilância direta da mãe biológica ou de mais alguém da família afim ou de sangue. Os batismos estabelecem regras de proteção e de dependências através de trocas de favores recíprocos, organizam hierarquias sociais, nem sempre muito nítidas e, quantas vezes, incômodas, seja naqueles ritos firmados entre senhores e escravos, seja em outros, entre escravos ou entre homens livres.

A experiência do "cravo-da-índia", gíria do século XIX, caracteriza um outro tipo de prática, antes um ritual de iniciação dos namoros, em relações domésticas voltadas para muitas vigilâncias e cercada de mal-estares. Mostra esse rito relações entre dois jovens rapazes, um universitário e outro escravo, desses com uma jovem dos segmentos médios urbanos e do jovem escravo com membros da família da moça. Informa sociabilidades desse ambiente em práticas destinadas a tecer e destecer vínculos peculiares a esse enlace. É exercido por "uma pessoa que se prestava a levar recados sobretudo amorosos", como indicado em nota pelo editor de A moreninha. ${ }^{13}$ Portador da confiança irrestrita das famílias em assuntos de intimidade, o "cravo-da-índia" tem muitos afazeres na trama dos romances a serem iniciados. As relações dos sexos feminino e masculino são orquestradas num constante leva-e-traz dos recados, num tempo de difíceis modos de comunicação, com o fim de cumprir um papel fundamental no desenvolvimento dos namoros. As mesmas tarefas podem aparecer como assemelhadas às da alcoviteira, em geral, mulher e guardiã dos mais íntimos segredos “da alcova”.

O "cravo-da-índia” desfruta de muitos ganhos com os privilégios familiares, mas também com o exercício de suas tarefas, cobrando pelos gastos de tempo a serviço de seu senhor ou senhora. O início do namoro de Joana e Fabrício, personagens desse romance, se dá no teatro quando um jovem escravo, acompanhante de Joana, sua mãe e sua irmã, se mantém como vigia à porta do camarote, e depois, regula o contato dos namorados, através de mímica. Tece o namoro, desde então. O gestual desse escravo faz Fabrício imediatamente identificá-lo como um "belíssimo cravo-da-índia”. Tobias, de 16 anos de idade - jovem, negro e escravo - revela seu poder de intermediação no rito do namoro dos jovens. É descrito em carta de Fabrício para Augusto como uma figura sem cerimônia e sem pudor, quando ao se apresentar, como es- 
cravo da mãe de Joana, viúva de um negociante e filha de um padre, propaga, desabridamente, tais condições familiares.

Tobias, logo que se aproxima de Fabrício, põe-se a propagandear, com orgulho, suas qualidades e habilidades: "meus parceiros me chamam orelha de cesto, pé de coelho e boca de taramela. Vá dizendo o que quiser, que em menos de dez minutos minha senhora saberá tudo...". E explica-se: "o recado de meu senhor é uma carambola que batendo no meu ouvido vai logo bater no da senhora d. Joaninha”. Fabrício não se enganara e se espanta com a rapidez com que o namoro é iniciado: "Ignoro de que meios se serviu Tobias para executar sua comissão. O que sei é que antes de começar o $2^{\circ}$ ato já eu havia feito o sinal, e então comecei a pôr em ação toda a mímica amantética que me lembrou: o namoro estava entabolado...”. Nesse jogo de interesses, Joana mantém discrição, informa Fabrício: “embora a moça não correspondesse aos sinais de meu telégrafo, concedendo-me apenas amiudados e curiosos olhares, isso já era muito para quem a via pela primeira vez". Os muitos gestos dessa "mímica amantética" ensinada por Tobias a Fabrício são traduzidos por Joana com o auxílio de Tobias.

As regras protocolares de aproximação de amor desses jovens, nesse espaço e tempo, só são possíveis com o auxílio de alguém como Tobias. A intermediação do "cravo-da-índia" nos namoros aparece como essencial. Códigos dominados por senhores e escravos revelam um pouco dessas complicadas tarefas de comunicação sobre assuntos da intimidade, lugar de muitos batismos. Na narrativa, a certa altura, o namoro com Joana tornara-se tão incômodo que Fabrício pedirá o auxílio de Augusto para livrar-se dele. Mas pesam nisso, mostra Fabrício, os constrangimentos que lhe são infligidos por Tobias tal o seu poder de barganha. São muitas e explícitas as exigências de Tobias: "Entende que todos os dias devo lhe dar dinheiro e persegue-me de maneira tal que, para ver-me livre dele, escorrego-lhe cum quibus, a despeito de minha má vontade”.

Andasse o namoro como andasse, o escravo Tobias está sempre a cobrar de Fabrício um pagamento sem fim: "O Tobias está no caso de muitos que, grandes e excelentes parladores, são péssimos financeiros na prática. Como eles fazem ao país, faz Tobias comigo, que sempre depois de longo discurso me apresenta um déficit e pede-me um crédito suplementar". As dificuldades de livrar-se desse insistente e poderoso negociador são assinaladas pelo missivista desolado, na sua impotência diante do prestígio desfrutado pelo escravo: "ele é a cria de d. Joaninha, o alfenin da casa, o São Benedito da família".

O compadrio entre homens ricos e pobres livres expõe ainda a busca de 
proteção de si e dos seus filhos; pode até ser definido como um emprego, caso do sr. Domingos Pais, personagem de José de Alencar, descrito em O tronco do ipê, como um exemplo de subalternidade em relação ao compadre abastado:

Esse curioso personagem ocupava na casa do Barão da Espera o emprego de compadre. Muitas pessoas talvez ignorem a natureza e importância deste cargo, que existe em quase todas as casas de ricos fazendeiros. Um compadre não é parente, nem hóspede, nem criado; mas participa dessas três posições; é um ente maleável que se presta a todas as feições e toma o aspecto que apraz ao dono da casa; é um apêndice da família da qual ele se incumbe de suprir quaisquer lacunas, e de apregoar as grandezas. Há na casa outros compadres, mas são conhecidos por seu nome: o compadre por excelência, o compadre da família, aquele que não precisa de outro qualificativo é ele, o homem de todas as ocasiões, o comensável festivo, pronto sempre para conversar, andar, jogar e comer, conforme a veneta do protetor a quem anexou-se. ${ }^{14}$

Alencar dá um tratamento jocoso a esse padrão de compadrio; conforme sejam as hierarquias sociais, expressa posições muito desiguais, de mando e de subordinação. Alencar revela seu menosprezo por ele:

Nenhum compadre acumulou jamais tão várias e importantes funções como o Sr. Domingos Pais. Era recado vivo para vizinhos, e bilhete de convite para as festas ou os banquetes. Servia de parceiro de solo, sendo preciso; fazia de carrancho no voltarete; jogava gamão com a baronesa, e o burro com as crianças que não terminavam sem deitar-lhe duas orelhas de papel. Fazia dançar as velhas e feias que não achavam par; estava sempre disponível para padrinho das crias da fazenda; ajudava a missa; e finalmente, além de muitas outras incumbências, paroquiava as bonecas de Alice, isto é celebrava os batizados e casamentos de brinquedo.

Segundo Alencar, esse tipo de compadre tem uma família “mas esta só lhe serve para formar pimpolhos que dão lugar ao compadresco e para exercitar a paciência indispensável ao bom desempenho de seu emprego. Como chefe de família, sua missão pois não é criar filhos, mas unicamente fabricar afilhados". Sabe-se pouco das extensões dessas práticas, mas elas impregnam fortemente as sociabilidades políticas dos dias atuais.

Há casos de padrinhos e madrinhas que se portam, efetivamente, como pais e mães em relações bastante igualitárias. Nesse caso, o batismo consolida práticas que podem transferir reciprocamente paternidades e maternidades 
com todas as suas responsabilidades para as pessoas nelas envolvidas. No caso, famílias, com e sem laços de consangüinidade, com freqüência, efetivam entre si tarefas de cuidados plenos de uma criança ou mais. $\mathrm{Na}$ falta definitiva ou temporária das mães, substituem-nas avós, tias, madrinhas, irmãs e irmãos mais velhos, agregados, várias vezes comadres e compadres, numa maternidade/paternidade transferida, reproduzindo vínculos íntimos das famílias extensas. Essa é a experiência vivida por Joaquim Nabuco. ${ }^{15}$ Anna Benigna de Sá Barreto, sua mãe, no momento de mudar-se, com seus cinco filhos, de Recife para a Corte, em 1849, acompanhando seu marido, José Thomaz Nabuco de Araújo, "fosse com receio de mudança, fosse por desejo dos padrinhos...", deixa Joaquim, recém-nascido, já no dia do batizado, com os padrinhos. A justificativa dessa maternidade transferida apóia-se no receio da mudança: viagem penosa, instalação da família, naquele momento, em nova residência, obrigações maternas com os filhos maiores e compromissos sociais que lhe impõe a vida na Corte, como mulher de deputado.

Anna Rosa de Carvalho, a madrinha, e o marido, proprietários do Engenho de Massangana em Pernambuco, tomam o menino como seu próprio filho e desde então, a madrinha "só vive para ele e não lhe pode negar as vontades”. Na Corte, a mãe biológica, Anna Benigna, vê-se às voltas com uma prole numerosa e intensa vida social por força da representação do marido. Joaquim Nabuco, só aos três anos de idade, por insistência de seus pais, será remetido ao Rio: "Vai o seu pequeno como pede, escreveu o padrinho. Estimarei que chegue a salvamento; é muito travesso e galante". Vive, então, essa criança, nessa visita, alguns estranhamentos. A madrinha toma conhecimento deles; além de não se conformar com sua ausência, teme a ameaça de que seja definitiva. Ao saber das dificuldades de adaptação do menino a sua família de sangue, manda um emissário ao Rio para saber da criança "pois fiquei bastante cuidadosa ... Era muito pequeno para ter tido tamanho choque. Perdoem dizer-lhes que vossas mecês foram culpados desses incômodos que tem tido meu filho ... bom é que ele venha mudar de ares; condição deu mandar buscá-lo (se for quando quiserem)".

Nessa experiência, estão em foco a proteção da criança pequena e indefesa, a programação de tempo da mãe no novo estilo de viver na Corte e também o poder de um casal sem filhos, de grande prestígio social, sobre o destino de um afilhado. A persistência da teia de proteção comunitária, tão forte nessa família extensa, inicialmente nada apresenta de ameaçador às famílias envolvidas; tudo se faz em nome das necessidades do recém-nascido, numa circunstância específica: a de mudança para o Rio e os problemas daí decor- 
rentes. O modo pelo qual Anna Rosa, madrinha e grande proprietária, adotara seu afilhado como filho, parece contrariar, por outro lado, aquele sentimento de indiferença pela criança, examinado por Ariès para os tempos que precedem a formação da família burguesa. Nesse caso, são muito fortes as disputas pela criança. A mãe tenta substituí-la com dificuldades: "A mãe se lhe afigura durante ainda bastante tempo como apenas uma rival daquela que ele não podia esquecer". A criança, impregnada do profundo afeto por sua madrinha, desse modo, estranhará a família biológica: Nabuco, num registro de próprio punho, diz sentir-se "como um órfão em casa de um tutor bondoso, onde todos se esforçam de o reconquistar" (1928, p.23).

O texto, em seguida, transcreve seus sentimentos nessa nova etapa de existência, no Rio, com os pais: "Meus pais então residiam numa grande casa de três andares, no fundo de um jardim todo enfeitado de animais de louça. Fez-me o efeito de um palácio. Não me lembro de ter tido emoção alguma ao encontrá-los; lembro-me apenas de ter sido examinado, observado...”. As disputas de afetos impulsionam lutas mesmo entre pessoas tão próximas e de mesma posição social, remetendo aos materiais invisíveis presentes nas redes sociais. Também colocam em cena a noção de "amor obsessivo", presumidamente peculiar à formação da família burguesa européia do século XIX, aquele que, admite-se, passa a dominar os adultos por suas crianças, ou as crianças por seus adultos, lembrando aquela exclusividade de afetos de que também fala Ariès.

Relações entre servidores domésticos livres e patrões organizam ritos de cuidados com crianças em sociabilidades que estabelecem elos de mesma força que a dos compadrios. No palácio imperial, na década de 1820 , as princesas imperiais, filhas de D. Pedro I e de Dona Leopoldina, dispõem de muitas amas portuguesas, cuja origem são famílias ligadas por laços ancestrais à realeza. Cumprem tarefas de cuidados diários, ritualmente organizados: essas amas as lavam, vestem-nas, alimentam-nas em vários horários de refeições, cuidam-lhes dos momentos e do preparo de seus repousos. ${ }^{16}$ Das tarefas de aprimoramento intelectual passa a se encarregar Maria Graham, inglesa, contratada como preceptora. Reconhecidamente culta, não apenas despreza os rústicos hábitos dessas amas, como assume, com a imperatriz, também estrangeira nessa corte, a missão de restringir-lhes incumbências. Na divisão de tempo e de tarefas que se desenvolve, mãe e educadora, cúmplices e ligadas por fortes laços de identidade cultural, buscam, juntas, para as princesas, livros e material de ensino e de aperfeiçoamento do espírito. Ambas introduzem alterações nos rituais de cuidados de orientação dessas amas. A educa- 
ção das princesas seria agora regulada através de aulas, passeios e folguedos em horários que se pretendem fixos, numa disciplina estranha às amas portuguesas e que as incomoda por reduzir-lhes o tempo de convivência com as princesas.

Nesse conflito, as relações entre as mulheres são conjugadas por antagonismos de classes e étnicos. O conflito culminaria com a dispensa da preceptora, tramada pelas amas, ancoradas em tradições palacianas da aristocracia portuguesa, e decidida pelo Imperador, de modo a afirmar essas tradições e ficar ao lado de seus súditos fiéis, ainda que com muitos constrangimentos para a Imperatriz e a inglesa... Mas também a solução seguinte e final não deixa de reduzir o poder dessas amas, quando coloca a gestão dessas tarefas nas mãos de uma dama da corte portuguesa, reconhecida por seu refinamento social e intelectual, indicada pelo alto clero da Igreja católica.

O desconhecimento e a incompreensão desses tantos ritos e das relações complexas que expressam são registrados, reiteradamente, por europeus recém-chegados ao Brasil nesse século. Com freqüência, manifestam aversão pelas relações escravistas ou por esses ritos domésticos que tanto estranhamento causou a Maria Graham e à Imperatriz. A todos falta a experiência secular desses batismos da intimidade; as experiências que portam os impedem de reconhecer os códigos locais. Pouco afeitos aos enlaces escravistas, os europeus chegados ao Brasil no século XIX, em geral, vão impor, no plano doméstico, fórmulas contratuais e de remuneração, distantes dos usos brasileiros.

As dificuldades vividas por Ernest Ebel na contratação inicial de uma mulher para os afazeres domésticos e sua substituição, logo a seguir, por um homem, são bem significativas do estranhamento que lhe causam essas regras da intimidade sob a escravidão. ${ }^{17}$ Vagas demográficas atuam, pois, sobre usuais relações da intimidade e seus ritos e, nessa contribuição, a vida doméstica no Rio também expõe ao longo desse século a incorporação de novas práticas e regras de convivência. Há fortes indícios, todavia, da persistência do largo espectro de obrigações pessoais na organização do espaço público; eles formatam relações políticas. O que está nas moradas está também no mundo que as cerca. Nos anos 20, acumulam-se indícios de que obrigações femininas, por outro lado, estão se transformando, quando entra em cena um volume crescente de mercadorias. ${ }^{18}$ Mudam os ritos domésticos, mudam as relações de dependência entre senhoras e escravas, e depois, com a abolição, entre crias e empregados/as domésticos/as. Hábitos domésticos movem-se entre práticas artesanais sempre associadas a modos de vida de natureza autárquica, em parte preservada, portanto, trabalhosas e árduas, de antigas tradições, 
mobilizando muitos trabalhos de escravas e escravos. Atualizam-se, porém, quando um conjunto de antigas práticas é substituída, total ou parcialmente, por mercadorias importadas, com muitos impactos sobre os ritmos do trabalho doméstico, a regulação do tempo feminino e o cotidiano da cidade. No desempenho de encargos e de obrigações familiares, atua ainda a forte valorização do aluguel da mão-de-obra escrava; ela introduz-se, aos poucos, no tecido das relações comunitárias e escravistas. Na crescente transferência de escravos para atividades de mercado, é perceptível que elos pessoais de outrora se redefinem, diante da progressiva introdução do trabalho livre em muitas atividades. Tarefas domésticas contaram, por muito tempo, com a presença marcante dos homens; esse é o caso dos cozinheiros: deslocados os homens para o mercado, essas tarefas serão exercidas por mulheres, numa nova divisão sexual do trabalho, como percebido por L. Edmundo. ${ }^{19}$

Tudo isso parece revolucionar as relações entre as esferas pública e privada e a intimidade das moradas na cidade e na região do Rio de Janeiro; de fato, tudo isso altera antigos ritos. É amplamente verificável que, nesse século e nessa região, persiste a transferência da maternidade de poucas mulheres que saem para o espaço público, para muitas outras pessoas (escravos/as, criados/as e empregados/as, vizinhos e familiares) que as assumem, em seu nome. Essa regularidade do regime escravista persiste mesmo quando itens de consumo mudam práticas domésticas, integral ou parcialmente, simplificando etapas e, quase sempre, redefinindo 'obrigações femininas'. Há muito por conhecer sobre os limites dos avanços tecnológicos no domínio da casa, considerando diferentes regimes de domesticidade. Dados demográficos desse século indicam proles numerosas e pré-destinam mulheres às tarefas de cuidados. Nessas condições, são muitas as tensões produzidas com as saídas das mulheres para o espaço público: as domesticidades vividas por mulheres de camadas médias e altas estreitam suas dependências com outras mulheres, escravas e empregadas domésticas. ${ }^{20} \mathrm{~A}$ redução de encargos domésticos depende de sistemas secundários de proteção social - aqueles formados por instituições públicas e privadas de cuidados diversos de crianças, velhos e doentes, amplamente desempenhados pelos sistemas primários, esses formados pelas redes familiares e de vizinhança, tradicionais e de baixo custo. Mesmo quando esses sistemas secundários se expandem, nunca chegam a substituir os primários; e isso cria embaraços às saídas das mulheres para o espaço público.

Em especial no Rio de Janeiro, a intensificação das saídas de mulheres de classes médias e altas do espaço doméstico para atividades da esfera pública, 
diante de conquistas de direitos sociais, sobretudo no que tange a acessos à educação, é sustentada por mulheres pobres na condição de cuidadoras - escravas e depois empregadas domésticas, sem remuneração ou precariamente remuneradas - às quais idênticos direitos são negados. Isso sem dúvida abre conflitos, só equacionados ao longo do século XX no campo dos direitos sociais.

Na medida em que o século XIX avança, obrigações e dependências recíprocas entre as pessoas de uma mesma morada se modificam. Isso se faz com antagonismos e consensos. Nas condições próprias esse antigos e novos modelos de organização familiar estão se efetivando e, neles, novos ritos. O modo urbano de morar favorece trocas, quando membros de famílias extensas habitam os mesmos domicílios ou próximos uns dos outros. Martins Pena, na peça teatral Quem casa, quer casa, encenada no Rio em 1845, anuncia tensões na formação de uma dada família nuclear - no caso, da pequena burguesia urbana. ${ }^{21}$ Título de peça, esse provérbio fala de laços de sangue e de afinidades e parece anunciar a noção de que, nessa conjuntura, ruptura de elos e agruras das famílias extensas estão em marcha. É certo que as famílias nucleares se formam e se expandem, mas quase nunca eliminam práticas comunitárias que, atualizadas, assentam-se em muitas redes sociais redefinidas. As famílias extensas prosseguem sob o advento da família nuclear. A experiência brasileira não anula de vez hábitos protecionistas e suas muitas conexões pessoais e comunitárias. Tanto é assim que dispensam investimentos públicos na esfera dos cuidados, como indicado. Mas também minguam e causam impactos: em fins do século, na cidade do Rio de Janeiro.

Cartas aos netos de Cristiano Ottoni e sua mulher, Bárbara Balbina, falam de sentimentos diante de sociabilidades transformadas. Vivem com Teodora, sua sogra e tia, e Teodósia, prima e cunhada; em 1885, registram muita tristeza nesse viver entre velhos. Com freqüência ficam sós, alternando-se em duas casas, uma no Rio e outra em Petrópolis. Embora dos seis filhos casados, quatro residam nessa mesma cidade, vêem-se diante de diásporas familiares por casamentos e sofrem com tantas ausências. ${ }^{22} \mathrm{O}$ espaço doméstico e seus ritos muito revelam desses tempos históricos de média e longa duração, quando dão visibilidade às "estruturas de sentimentos", a que se refere Raymond Williams, lembrado por Marcelo Ridenti em texto recente, modo de sinalizar a marca dos tempos em tensões e conflitos e seus muitos significados. ${ }^{23}$ Moradas e sociabilidades transformadas em muitos ritos domésticos e religiosos prosseguem exibindo muitos sinais políticos, feitos e desfeitos, em práticas sociais. $\mathrm{Na}$ experiência brasileira, as moradas quando expõem relações 
de gênero, raças/etnias, classe, e gerações em suas muitas interseções e complexidades, oferecem à análise histórica alguns informes e muitos desafios.

\section{NOTAS}

${ }^{1}$ Um marco nessas revisões são os debates de Sidney Chalhoub em relação aos conceitos de Jacob Gorender sobre o escravismo colonial, em fins dos anos 80. Trabalhos de Sylvia H. Lara, de Sheila de Castro Faria, de Hebe Castro, de José Roberto Góes, de Renato Pinto Venâncio e Robert Slenes trazem importantes contribuições sobre a matéria. Mais recentemente, estudos sobre cidadania na Brasil as têm ampliado.

${ }^{2}$ RÉMOND. R. “Do Político”. In: Por uma história política. 2.ed. Trad. Dora Rocha. Rio de Janeiro: Ed. FGV, 2003. p.445.

${ }^{3}$ Sobre "horizonte de expectativas", ver: KOSELLECK, R. "Champ d'experience" et "horizon d'attente": deux catégories historiques. In: - Le futur passé. Contribution à la sémanthique des temps historiques. Paris: Éd. de l'EHESS, 1990. p.307-329; CEFAÏ, Daniel. "Experience, Culture et Politique". In: Cultures politiques. Paris: PUF, 2001. p.93-116; DUTRA, Eliana R. de F. História e culturas políticas: definições, usos, genealogias. In: Varia História, Programa de Pós-Graduação em História/UFMG, n.28, 2001. Belo Horizonte: Dep. de História da Fafich/UFMG, 2002, p.13-28.

${ }^{4}$ Ver: COSTA, S. G. "Globalização e intimidade. Rio de Janeiro, século XIX”. R IHGB, Rio de Janeiro, v.167, n.433, p.63-86, out.-dez. 2006.

${ }^{5}$ DEBRET, J. B. Viagem pitoresca e histórica ao Brasil. Prefácio A. C. Villaça. Belo Horizonte: Itatiaia, 1989. Tomo III (Coleção Reconquista, 3aㅗ série, v.7). Contém aquarela e desenhos que não foram reproduzidos na edição de Firmin Didot, 1834. Publicada em Paris: R. de Castro Maya Ed., 1954. p.149-150.

${ }^{6}$ Cf. DEBRET, J. B., 1954, Tomo III (Aquarelas...), E.105, p.8.

${ }^{7}$ Carta n.18, de abril de 1812, p.73-74. In: MINISTÉRIO DA EDUCAÇÃO E SAÚDE. Cartas de Luiz Joaquim dos Santos Marrocos. Anais da Biblioteca Nacional, v. LVI, 1939. (Separata. $\mathrm{BC})$.

${ }^{8}$ ALMEIDA, M. A. Memórias de um sargento de milícias. 17.ed. São Paulo: Ática, 1990. p.77.

${ }^{9}$ BURLAMAQUE, Frederico Leopoldo César. Memória analítica acerca do comércio de escravos e acerca dos males da escravidão doméstica. In: COSTA, João Severiano M. da et al. Memórias sobre a escravidão, p.212. (grifo meu).

${ }^{10}$ BINZER, I von. Os meus romanos. Alegrias e tristezas de uma educadora alemã no Brasil. Trad. A. Rossi e L. da G. Cerqueira. 3.ed. Rio de Janeiro: Paz e Terra, 1982. p.35.

${ }^{11}$ Apud TAUNAY, A. de E. (Visconde de Taunay). Rio de Janeiro de antanho: impressões de viajantes estrangeiros. São Paulo: Cia. Ed. Nacional, 1942. (BC), p.365-367. 
${ }^{12}$ EXPILLY, C. Mulheres e costumes do Brasil. 2.ed. Trad. G. Penalva. São Paulo: Cia. Ed. Nacional, 1977. p.15.

${ }^{13}$ MACEDO, J. M. A moreninha. 14.ed. São Paulo: Ática, [196-?], p.35.

${ }^{14}$ ALENCAR, J. O tronco do Ipê. São Paulo: Saraiva, 1965. p.245.

${ }^{15}$ NABUCO, C. A vida de Joaquim Nabuco [por sua filha Carolina Nabuco]. Rio de Janeiro: Cia. Ed. Nacional, 1928. p.20-21.

${ }^{16}$ CORRESPOND NCIA entre Maria Graham e a Imperatriz Dona Leopoldina e cartas anexas. Anais da Biblioteca Nacional, Rio de Janeiro, v.60, 1940, p.102-115.

${ }^{17}$ EBEL, E. O Rio de Janeiro e seus arredores em 1824. Trad. J. de S. Leão Filho. São Paulo: Cia. Ed. Nacional, 1972. p.25-30.

${ }^{18}$ Ver: COSTA, S. G., 2006; idem, Metáforas do tempo e do espaço doméstico. Rio de Janeiro, século XIX. Tese (Doutorado) - Programa de Pós-Graduação em História, UFF, Niterói, 1996. Ver, em especial, p.567-576.

${ }^{19}$ EDMUNDO, L. O Rio de Janeiro no tempo dos Vice-Reis. 3.ed. Rio de Janeiro: Aurora, 1951. v.1, p.343-344.

${ }^{20}$ Sobre o assunto, ver: COSTA, S. G. Proteção social, maternidade transferida e lutas pela saúde reprodutiva. Estudos feministas, Florianópolis: CFH/CCE/UFSC, n.2, v.10, p.301324, $2^{\circ}$ sem. 2002; COSTA, S. G. Das desventuras de ser doutora. Espaço feminino Uberlândia: Universidade Federal de Uberlândia, n.15, 2004, p.103-116.

${ }^{21}$ MAGALHÃES JUNIOR., R. Martins Pena e sua época. 2.ed. São Paulo: Lisa, 1972.

${ }^{22}$ Ver: OTTONI, Cristiano B.; OTTONI, Bárbara B. de A. M. Cartas aos netos. Rio de Janeiro: Arquivo Nacional, 1978.

${ }^{23}$ RIDENTI, M. “Artistas e política no Brasil pós-1960. Itinerários da modernidade”. In: RIDENTI, M.; BASTOS, E. R.; ROLLAND, D. (Org.). Intelectuais e Estado. Belo Horizonte: Ed. UFMG, 2006. Refere-se a WILLIAMS, R. Marxismo e literatura. Trad. Waltensir Dutra. Rio de Janeiro: Zahar, 1979. Sobre o assunto, ver ainda: LÖWY, M. "Romantismo e marxismo”. In: COGGIOLA, O. (Org.). Marxismo hoje. São Paulo: Xamã; FFLCH-USP, 1994.

Artigo recebido em novembro de 2007. Aprovado em dezembro de 2007. 